\title{
Aerial VFA in Livestock Houses and Animal Waste Treatment Facilities
}

\author{
Hiroshi Tanaka, Kazutaka Kuroda, Takashi Osada, \\ Michihiro Yonaga, Mutsumi SuzUKI* \\ and Mitsuru INABA** \\ National Institute of Animal Industry, Tsukuba Norin \\ kenkyudanchi, Ibaraki-ken 305 \\ ${ }^{*}$ Gunma Agricultural Research Center, Fujimi-mura, \\ Gunma-ken 371-01 \\ ** Shizuoka Swine and Poultry Experiment Station, \\ Kikugawa-cho, Shizuoka-ken 439
}

(Received February 12, 1991)

\begin{abstract}
A field survey on VFA from livestock facilities was carried out mainly on those of National Institute of Animal Industry and of two commercial pig enterprises to find out a countermeasure for reducing the evolution. VFA were analyzed by the alkali beads method of the Offensive Odor Control Law with modifications. Little odors were emitted from layer houses well managed and equipped with slats and improved watering systems and VFA were below $2.4 \mathrm{ppb}$. Whereas, in a broiler house with old newspaper bedding, the aerial VFA, especially n-butyric acid $\left(C_{4}\right)$ increased remarkably to reach $97.4 \mathrm{ppb}$ with accumulation of litter followed by the moistening, and the aerial ammonia concentrations also increased to $20.3 \mathrm{ppm}$. In dairy barns VFA in the air were on low levels except for silage feeding time, when propionic acid $\left(\mathrm{C}_{3}\right)$ and $\mathrm{C}_{4}$ increased to higher levels. In general, aerial VFA in poultry and cattle houses are assumed to stay on low levels as long as proper waste management and silage handling is performed. Pig houses of partly slatted floor structures with pit scrapers and augers or with liquid manure systems were very odorous; in the latter, VFA in the air amounted to more than a hundred $\mathrm{ppb}$. In pig houses with well managed sawdust floors, however, odors and VFA were in low levels, with $C_{3}$ and $C_{4}$ below $5.9,2.2$ ppb resp., both in summer and in winter. No offensive odors of VFA were emitted from the waste treatment facilities investigated, except a greenhouse for drying and composting swine manure, indicating biological treatments to be effective methods in controlling VFA from animal wastes.
\end{abstract}

Anim. Sci. Technol. (Jpn.) 62 (10) : 955-962, 1991

Key words: VFA, ammonia, odor, livestock house, animal waste

A recent trend toward large confinement livestock production in restricted areas, coupled with urban sprawl, is enhancing the risk of environmental problems, which suppress livestock farming. Among the problems, odor complaints are generated most frequently. Volatile fatty acids (VFA) are main components of malodors ${ }^{3,4,8,11,15,16)}$ emitted from livestock farms, and are known to enhance offensive odors in the presence of other components, such as sulfur compounds, phenols, and indoles ${ }^{2,9,10,13,14)}$. Recently, an extensive field survey was performed by the Environment Agency ${ }^{1)}$ on aerial VFA in agricultural and food industries and it was confirmed that VFA are responsible for odors from livestock 
facilities, especially swine houses, and from rendering plants, starch factories, etc. Upon these data, the Agency published the regulation of four VFA; propionic $\left(\mathrm{C}_{3}\right)$, n-butyric $\left(\mathrm{C}_{4}\right)$, $\mathrm{n}$-valeric $\left(\mathrm{C}_{5}\right)$ and iso-valeric acids $\left(\mathrm{i}-\mathrm{C}_{5}\right)$; in April 1990, by revising the Offensive Odor Control Law (OOCL) ${ }^{\prime}$. Since those VFA, especially the latter three, have lower thresholds for the olfaction, the regulatory standards on boundary lines have been established as low as ppb or sub-ppb levels according to the categories of the areas.

In order to establish countermeasures for controlling emissions of odors from livestock facilities, it is important to investigate the actual conditions of the odor emissions. This paper reports on the analyses of VFA in the air of livestock houses and of the waste treatment facilities.

\section{Materials and Methods}

1. Farms and waste treatment facilities investigated

During the past two years (1989-1990), animal and poultry houses and waste treatment facilities were investigated for VFA in the air. These houses and facilities were located in Ibaraki ( 3 poultry, 10 swine, and 2 cattle houses and 4 waste treatment facilities), Saitama (a waste treatment facility), Gunma ( 3 waste treatment facilities), Mie ( 2 cattle houses and a waste treatment facilities), and Aichi (2 poultry, and a swine houses and 2 waste treatment facilities) prefectures. Especially, detailed investigations were performed on those of the National Institute of Animal Industry (NIAI) and on farrow-to-finish swine farms $O$ and $M$ in Tsuchiura City, with 90 and 135 sows resp. Air samples were collected about $1 \mathrm{~m}$ above floors, and analyzed in duplicates unless otherwise stated.

2. Analytical methods

1) VFA determination

VFA, the four regulated acids as well as iso-butyric $\left(\mathrm{i}-\mathrm{C}_{4}\right)$ and 2 -methylbutyric $(2-\mathrm{Me}-$
$\mathrm{C}_{4}$ ) acids, were analyzed by gas chromatography, according to the method of $\mathrm{OOCL}^{13}$ and to those of Hoshica ${ }^{5,6)}$ and KATou et al. ${ }^{7)}$ with the following modifications.

(a) Air sampling tube: A pyrex tube 5.8$\mathrm{mm}$ in i.d., $15 \mathrm{~cm}$ long, with a tapered end to fit a syringe needle, was packed with about $2.5 \mathrm{~g}$ of alkali glass beads, which were prepared from $100 \mathrm{~g}$ of glass beads (about $0.63 \mathrm{~mm} \mathrm{~d}$.) by addition of $0.3 \mathrm{~g}$ of $\mathrm{Sr}(\mathrm{OH})_{2} \cdot 8 \mathrm{H}_{2} \mathrm{O}$ in $100 \mathrm{~m} l$ of distilled water and subsequent evaporation with a rotary evaporator. After conditioning by heating for $10 \mathrm{~min}$ at $280^{-}$ $300^{\circ} \mathrm{C}$ in a stream of nitrogen gas, it was sealed with a Teflon cap and a silicone septum, and wrapped with Parafilm $M$ to store until use.

(b) Gas chromatography: It was conducted on a JEOL $20 \mathrm{~K}$ chromatograph fitted with a flame ionization detector and a switching valve for nitrogen carrier gas. The column was prepared as follows ; a glass column, $1.6 \mathrm{~m} \times$ $3 \mathrm{~mm}$ i.d., was packed with Carbopack B $(60 / 80$ mesh). Each $30 \mathrm{mg}$ of FFAP (free fatty acid polyester) and phosphoric acid were dissolved in $30 \mathrm{ml}$ of methanol, and the solution was passed through the column in 10 hours. During the coating, the column was treated with ultrasonic wave for $5 \mathrm{~min}$. Then, the column was conditioned overnight at $220^{\circ} \mathrm{C}$ in a stream of nitrogen gas. The chromatographic conditions were as follows ; carrier gas was nitrogen, $43 \mathrm{ml} / \mathrm{min}$. Injection and detection was operated at $200^{\circ} \mathrm{C}$ and the oven heating was programmed from $100^{\circ} \mathrm{C}$ to $200^{\circ} \mathrm{C}$ at $6^{\circ} \mathrm{C} / \mathrm{min}$.

(c) Analytical procedure : Using a portable air pump, Sibata MP-50 WT, $12.5 \mathrm{l}$ of the air in the field was passed through the sampling tube in $6 \mathrm{~min}$. Before the GC analysis, the tube was heated in a nitrogen gas stream at $180^{\circ} \mathrm{C}$ for $5 \mathrm{~min}$ to expel contaminants. Then, the tube was fitted with a syringe needle, and added with $5 \mu l$ of formic acid (GR MERK, the earlier main distillate), while being held in horizontal position. Immediately after the 
addition, the tube was connected to the carrier gas by a Swagelok fitting and the needle was inserted to the injection port of the gas chromatograph. At the same time the carrier gas was allowed to pass through the tube by the switching valve and the tube was heated to $200^{\circ} \mathrm{C}$ in 2 min to start chromatography. Af ter each analysis, the chromatograph was injected with $4 \mu l$ of $5 \%$ formic acid to remove any residual VFA.

2) Ammonia determination

In addition to VFA analyses, ammonia concentrations in the air were determined by detection tubes (Gastec, $3 \mathrm{~L}$ ).

\section{Results and Discussion}

The results of VFA and ammonia analyses on livestock facilities are shown in Table 1-4, as the averages of duplicate determinations.

In the layer houses of NIAI (Table 1,Sample No. 1, 2; August), aerial VFA were on low levels, ranging from trace to $1.4 \mathrm{ppb}$, in accord with daily removal of the waste. Thus, air sample (No. 5) taken at $30 \mathrm{~cm}$ above droppings on the floor was found to contain less than 5.8 ppb VFA. Odors from layer houses (No. 3, 4 ; December) of poultry enterprises in Aichi were also below a few ppb. These houses were equipped with slats under the cages in addition to improved waterers to keep droppings dry. In accord with low odors, VFA and ammonia levels in the air were low. Whereas, in the windowless broilerhouse in NIAI, where old newspapers were used as a bedding material, aerial VFA increased with accumulation of the waste on the bedding, and at two weeks of age $\mathrm{C}_{4}$ reached to a peak of $15.7 \mathrm{ppb}$ (No. 6). The VFA, then, decreased gradually in accord with increase of ammonia concentration in the air.

The air samples from the dairy barn of NIAI had VFA in small amounts (Table 2, No. 1, 6). Near a silo attached to the barn, or during delivery of silage, however, VFA in the air of the barn, especially $\mathrm{C}_{3}$ and $\mathrm{C}_{4}$ increased up to 30.8 and $13.4 \mathrm{ppb}$ resp. (No. 5, 2). These large values were observed for $\mathrm{C}_{3}$ in winter (No. 3-6) and for $\mathrm{C}_{4}$ in summer (No, 2).

In the air of a beef cattle barn with sawdust bedding (No. 7, March) in Mie only traces of VFA were detected, but in the barn of NIAI with old nowspaper bedding (No.9, 10) the atmospheric VFA were on higher levels, and especially $\mathrm{C}_{4}$ concentrations were about $10 \mathrm{ppb}$ in June. The differences in $C_{3}$ and $C_{4}$ concentrations in the cattle barns appear to be seasonal fluctuations and assumed to be due to the quality of silage.

Anyhow, in poultry houses and cattle barns, the aerial VFA will be estimated not to be a nuisance, so long as the accumulated manure and silage are managed properly. However, one should not assume from these data that

Table 1. VFA in the Air of Poultry Houses (1989-1990*)

\begin{tabular}{|c|c|c|c|c|c|c|c|c|c|c|}
\hline $\begin{array}{l}\text { sampling } \\
\text { No. Date }\end{array}$ & ${ }^{\text {temp }}$ & $\begin{array}{l}\text { wind } \\
\mathrm{m} / \mathrm{s}\end{array}$ & $\begin{array}{l}\mathrm{NH}_{3} \\
\mathrm{ppm}\end{array}$ & $\begin{array}{ll}3 & \mathrm{C}_{3} \\
n^{2}\end{array}$ & $i-C_{4}$ & $\mathrm{C}_{4}$ & $\begin{array}{l}2-\mathrm{Me}^{-} \mathrm{C}_{4} \\
\mathrm{ppb}\end{array}$ & $\mathrm{i}-\mathrm{C}_{5}$ & $\mathrm{C}_{5}$ & $\begin{array}{l}\text { description on } \\
\text { sampling place }\end{array}$ \\
\hline 1 Aug 11 & 24.3 & 0.0 & 3.3 & 1.4 & - & 0.6 & - & 0.2 & ND & WL, L, NIAI \\
\hline 2 Aug 11 & 27.8 & 1.3 & 0.2 & $\mathrm{ND}$ & - & ND & - & ND & ND & $\mathrm{L}, \mathrm{NIAI}$ \\
\hline 3 Dec 12 & 16.0 & 0.6 & ND & 2.4 & 0.4 & 0.7 & 0.2 & 0.2 & 0.2 & $\mathrm{~L}$, slat, nipple $\mathrm{D}$, Aichi \\
\hline 4 Dec 12 & 16.2 & 0.3 & ND & 0.8 & 0.1 & 0.2 & 0.1 & 0.3 & 0.4 & $\mathrm{~L}$, slat, trough $\mathrm{D}$, Aichi \\
\hline 5 Aug $21^{*}$ & 24.2 & 0.03 & 3.5 & 3.5 & 5.8 & 3.5 & 0.4 & 0.7 & 0.6 & WL, L\#, NIAI \\
\hline 6 Nov $9^{*}$ & 25.3 & 0.05 & 0.1 & 2.4 & 1.5 & 15.7 & 0.9 & 2.5 & 1.0 & WL, $B \#, 2$ w of age, NIAI \\
\hline 7 Dec $21^{*}$ & 20.4 & 0.08 & 20.3 & 61.5 & 10.1 & 97.4 & 6.4 & 6.7 & 3.3 & WL, $B \# \#, 8 w$ of age, NIAI \\
\hline
\end{tabular}

$\mathrm{C}_{3}$ : propionic acid; $\mathrm{i}-\mathrm{C}_{4}:$ iso-butyric acid; $\mathrm{C}_{4}: \mathrm{n}$-butyric acid; $2-\mathrm{Me}_{4}-\mathrm{C}_{4}: 2-$ methylbutyric acid; i$\mathrm{C}_{5}$ : iso-valeric acid; $\mathrm{C}_{5}:$ n-valeric acid; \# : old newspaper bedding; ND : not detected WL : windowless; L : layer house; $B$ : broiler house; $\$ 30 \mathrm{~cm}$ above feces on the floor; $D:$ drinker 
higher levels of VFA could not or did not occur ; in the case of the floor-reared broiler in NIAI, VFA concentrations in the air increased again and aerial $\mathrm{C}_{4}$ amounted to $97.4 \mathrm{ppb}$, afterwards, with increasing moisture of the litter with spilled water, irrespective of presence of very high aerial ammonia of $20.3 \mathrm{ppm}$, as the waste was accumulated and moistened severely (Table 1, No. 7).

VFA of higher concentrations of several decades ppb were frequently found in the air of pig houses (Table 3). In the fattening house in

Table 2. VFA in the Air of Cattle Barns (1989-1990*)

\begin{tabular}{|c|c|c|c|c|c|c|c|c|c|c|}
\hline $\begin{array}{l}\text { sampling } \\
\text { No. Date }\end{array}$ & ${ }^{\operatorname{tem}} \mathrm{C}$ & $\begin{array}{l}\text { wind } \\
\mathrm{m} / \mathrm{s}\end{array}$ & $\begin{array}{r}\mathrm{NH}_{3} \\
\mathrm{ppm}\end{array}$ & $\mathrm{C}_{3}$ & $\mathrm{i}-\mathrm{C}_{4}$ & $\mathrm{C}_{4}$ & $\begin{array}{c}2-\mathrm{Me}^{-\mathrm{C}_{4}} \\
\mathrm{ppb}\end{array}$ & $\mathrm{i}^{-\mathrm{C}_{5}}$ & $\mathrm{C}_{5}$ & $\begin{array}{l}\text { description on } \\
\text { sampling place }\end{array}$ \\
\hline 1 Aug 11 & 27.2 & $0.0-0.1$ & 0.1 & 0.2 & - & 0.4 & - & $\mathrm{ND}$ & ND & $D^{\#}$, NIAI \\
\hline 2 Aug 11 & 27.0 & $0.0-0.3$ & 0.1 & 1.7 & - & 13.4 & - & 0.7 & ND & $D^{\#}, \mathrm{FS}, \mathrm{NIAI}$ \\
\hline 3 Nov 27 & 13.9 & $0.1-1.5$ & -1 & 17.8 & 0.6 & 0.7 & 0.1 & 0.2 & 0.1 & $D$, end of passage, NIAI \\
\hline 4 Nov 27 & 10.5 & - & -1 & 11.3 & 0.3 & 0.5 & 0.1 & 0.2 & 0.3 & D, mid passage, NIAI \\
\hline 5 Nov 28 & 18.9 & $0.1-0.2$ & -3 & 30.8 & 0.9 & 2.4 & 0.2 & 0.4 & 0.3 & age, NIAI \\
\hline 6 Nov 28 & 14.5 & $0.0-0.1$ & - & 6.5 & 0.3 & 0.6 & 0.2 & 0.2 & 0.3 & ssage, NIAI \\
\hline 7 Mar $19^{*}$ & 17.1 & $0.1-0.7$ & - & 0.1 & 0.1 & 0.2 & ND & ND & $\mathrm{ND}$ & $B$, sawdust bedding, Mie \\
\hline $8 \operatorname{Mar} 20^{*}$ & 19.6 & $0.0-1.6$ & - & 0.8 & 0.6 & 0.6 & 0.2 & 0.2 & 0.3 & $\mathrm{D}, \mathrm{Mie}$ \\
\hline 9 Jun $20^{*}$ & 26.0 & 0.03 & 2.0 & 2.4 & 0.6 & 9.2 & 0.3 & 0.8 & 0.7 & $B$, before SM \& FS, NIAI \\
\hline 10 Jun $20^{*}$ & 26.6 & $0.2-1.5$ & 2.5 & 3.9 & 0.7 & 10.8 & 0.8 & 0.6 & ND & $B$, during SM \& FS, NIAI \\
\hline
\end{tabular}

$\mathrm{D}$ : dairy barn; $\mathrm{B}$ : beef cattle barn; $\#:$ most cows were in a paddock; ${ }^{* *}$ : FS : feeding with silage SM : scraping \& removal of manure; end of passage : at the end of passage near a silo

Table 3. VFA in the Air of Pig Houses (1989-1990*)

\begin{tabular}{|c|c|c|c|c|c|c|c|c|c|c|}
\hline $\begin{array}{l}\text { sampling } \\
\text { No. Date }\end{array}$ & ${ }^{\text {temp }} \mathrm{C}$ & $\begin{array}{l}\text { wind } \\
\mathrm{m} / \mathrm{s}\end{array}$ & $\begin{array}{l}\mathrm{NH}_{3} \\
\text { ppm }\end{array}$ & $\mathrm{C}_{3}$ & $\mathrm{i}-\mathrm{C}_{4}$ & $\begin{array}{l}\mathrm{C}_{4} \\
\mathrm{ppb}\end{array}$ & $2-\mathrm{Me}^{-\mathrm{C}}$ & $\mathrm{C}_{4} \mathrm{i}-\mathrm{C}_{5}$ & $\mathrm{C}_{5}$ & $\begin{array}{l}\text { description on } \\
\text { sampling place }\end{array}$ \\
\hline $1 \mathrm{Jul} 7$ & 28.3 & moderate & - & 6.0 & - & 0.5 & - & 0.5 & 0.3 & $F$ house, NIAI \\
\hline 2 JuL 14 & 29.0 & moderate & - & 4.4 & - & 1.6 & - & 0.6 & 0.9 & $F$ house, NIAI \\
\hline 3 Jul 21 & 30.5 & $0.1-0.5$ & 3.0 & 58.7 & - & 41.4 & - & 3.0 & 8.2 & F house-1, scraper, $O$ \\
\hline 4 Jul 21 & 30.5 & $0.0-0.1$ & 1.0 & 20.2 & - & 12.0 & - & 1.9 & 2.5 & FR house, scraper, $\mathrm{O}$ \\
\hline 5 Jul 21 & 30.5 & $0.2-1.1$ & 1.0 & 38.6 & - & 33.9 & - & 3.1 & 4.8 & $F$ house-2, scraper, $O$ \\
\hline 6 Jul 21 & 30.5 & $0.6-1.6$ & 1.5 & 39.9 & - & 48.5 & - & 2.9 & 6.2 & Outside, 0 \\
\hline 7 Jul 28 & 31.0 & $0.2-1.0$ & 6.0 & 170 & - & 131 & - & 10.3 & 22.9 & $\mathrm{~N}$ house, liquid, $\mathrm{M}$ \\
\hline 8 Jul 28 & 29.0 & $0.2-1.3$ & 2.0 & 20.7 & - & 21.1 & - & 2.5 & 5.5 & FR house, liquid, $M$ \\
\hline $9 \mathrm{Jul} 28$ & 29.5 & $0.2-1.0$ & 3.0 & 28.2 & - & 18.6 & - & 2.5 & 3.0 & F house-1, scraper, $M$ \\
\hline 10 Jul 28 & 29.5 & $0.3-1.2$ & 5.0 & 48.7 & - & 33.3 & - & 3.7 & 5.3 & $F$ house-2, scraper, $M$ \\
\hline 11 Nov 30 & 13.8 & $0.5-1.4$ & 1.0 & 23.3 & 2.9 & 16.2 & 1.4 & 1.1 & 2.3 & Outside, $\mathrm{O}$ \\
\hline 12 Nov 30 & 19.0 & $0.1-0.3$ & 6.5 & 5.9 & 1.5 & 2.0 & 0.5 & 0.7 & 0.5 & $F$ house -3 , SD floor, $\mathrm{O}$ \\
\hline 13 Nov 30 & 14.6 & $0.1-0.5$ & 2.5 & 0.7 & 0.7 & 0.9 & 0.2 & 0.2 & 0.4 & F house-4, SD floor, $\mathrm{O}$ \\
\hline $14 \operatorname{Dec} 13$ & 19.2 & $0.0-0.2$ & 6.0 & 77.6 & 10.0 & 35.4 & 4.9 & 4.3 & 5.4 & WL FH, scraper, Aichi \\
\hline $15 \mathrm{Jul} 27^{*}$ & 31.2 & 0.39 & 0.3 & 3.8 & 1.4 & 2.2 & 0.6 & 1.7 & 0.7 & $F$ house -3 , SD floor, $\mathrm{O}$ \\
\hline 16 Jul $27^{*}$ & 28.8 & 1.11 & $\mathrm{ND}$ & 2.1 & 0.6 & 1.5 & 0.6 & 0.7 & 0.7 & $\mathrm{~F}$ house-4, SD floor, $\mathrm{O}$ \\
\hline $17 \mathrm{Jul} 27^{*}$ & 29.3 & 0.59 & 0.1 & 43.1 & 3.9 & 37.9 & 2.6 & 3.5 & 5.6 & $F$ house-2, scaper, $O$ \\
\hline $18 \mathrm{Jul} 27^{*}$ & 30.7 & 1.02 & 0.1 & 13.6 & 1.3 & 11.1 & 0.9 & 1.5 & 2.2 & Outside, O \\
\hline
\end{tabular}

$F$ : fattening; $N$ : nursery; FR : farrowing; $O: O$ farm; $M: M$ farm; SD : sawdust; WL : windowless Outside : $10 \mathrm{~m}$ downwind from the exhaust fan of $\mathrm{F}$ house-2, 0 
NIAI (No. 1,2), the aerial VFA were below several ppb due to lower housing density and better management.

In contrast, intense malodors were emitted from the nursery and fattening houses of pig enterprises, $\mathrm{O}$ and $\mathrm{M}$ farms (No. 3,$5 ; 7,9,10$ ) and the VFA of $\mathrm{C}_{3}, \mathrm{C}_{4}, \mathrm{i}-\mathrm{C}_{5}$ and $\mathrm{C}_{5}$ were extremely high $\left(28-170,19-131,2.5-10.3,3.0^{-}\right.$ $22.9 \mathrm{ppb}$ resp.) in summer. In these farms, even the atmospheres of farrowing houses were malodorous (No. 4,8). Especially in the nursery house that were constructed by underslat liquid manure systems, the odors were more offensive to record the highest values of the aerial VFA, when aerial ammonia concentration amounted to $6 \mathrm{ppm}$ (No. 7). Similarly, both aerial VFA and ammonia were high $\left(\mathrm{C}_{4}\right.$ $35.4 \mathrm{ppb}$; ammonia $6 \mathrm{ppm})$, when determined in winter, in a windowless fattening building (No. 14) with partly slatted floors in Aichi, whereas the outside of the building was not odorous, suggesting the exhaust odors to be allowed to diff use effectively.

Those pig houses that evolved large amounts of VFA were of partially slatted floor structures and equipped with scrapers and augers in the pits, or with liquid manure pits, where excreta became anaerobic during scraping or storage to give rise to malodors. Thus, even in the air outside of the fattening house- 2 of $\mathrm{O}$ farm (No.6,11,18; $10 \mathrm{~m}$ downwind of the exhaust fan), VFA were beyond the levels regulated by OOCL.

On the contrary, the piggeries with saw dust floors of $\mathrm{O}$ farm (No. 12, 13, 15, 16) were not so odorous and the VFA $\left(\mathrm{C}_{3}, \mathrm{C}_{4}, \mathrm{i}-\mathrm{C}_{5}\right.$, and $\left.\mathrm{C}_{5}\right)$ in the air were below 5.9,2.0, 0.7 and $0.5 \mathrm{ppb}$ resp., whereas the aerial ammonia was rather higher, in winter when the windows were almost closed. In these piggeries, the acids stayed in below several ppb even in summer, though all the windows were open and the exhaust fans were working. The reason for less odors in these piggeries lies in management of the sawdust floors: The sawdust floors were black in color and properly moistened to allow in-house composting of the accumulated manure to decompose VFA. Here, resultant ammonium ion is assumed to serve for suppressing the vaporization of VFA by forming the salts.

In contrast to these piggeries, the VFA in the air of the above house-2 (No. 17) were found again in high levels and $\mathrm{C}_{3}, \mathrm{C}_{4}, \mathrm{i}-\mathrm{C}_{5}$, and $\mathrm{C}_{5}$ were $43.1,37.9,3.5$ and $5.6 \mathrm{ppb}$ resp. on the same day in summer.

The waste treatment facilities including plastic covered greenhouses for composting and drying wastes (Table 4, No. 3, 8, 13), composters (No. 1, 10), compost storage (No. 2, 4, $5,6,9)$ and waste water treatment systems (No. 7, 11, 12,13) were also investigated for the VFA in the air. Since biological degradation of organic materials is involved in the most waste treatment processes and results in producing a large amount of ammonium ion as envisaged on composting of manure, evolution of VFA from the wastes can be expected to be suppressed by neutralization with abundant ammonium ion and by vigorous microbial decomposition.

Expectedly, the treatment facilities investigated had no acidic odors of VFA (below $2.9 \mathrm{ppb}$ ), except the greenhouse containing an aerated composter for swine feces (Table 4 , No. 8) in Saitama, where $\mathrm{C}_{4}$ in the air at the entrance amounted to $35.5 \mathrm{ppb}$, though aerial ammonia was considered to be in high levels. In this case, the VFA were assumed to arise mainly from storage of raw swine feces scraped out from pits and not from the compost product.

In addition to the treatment facilities, both VFA and ammonia were simultaneously released from some livestock houses, including the above broiler house (Table 1, No. 6, 7) and pig houses, in high concentrations, though they are readily reactive to give salts.

Formerly, we reported that odors in the exhaust from composting of pig feces were 
Tanaka, Kuroda, Osada, Yonaga, Suzuki and Inaba

Table 4. VFA in the Air of the Waste Treatment Facilities (1989-1990*)

\begin{tabular}{|c|c|c|c|c|c|c|c|c|c|c|}
\hline $\begin{array}{l}\text { sampling } \\
\text { No. Date }\end{array}$ & $\underset{{ }^{\circ} \mathrm{C}}{\text { temp }}$ & $\begin{array}{l}\text { wind } \\
\mathrm{m} / \mathrm{s}\end{array}$ & $\begin{array}{l}\mathrm{NH}_{3} \\
\text { ppm }\end{array}$ & $\mathrm{C}_{3}$ & $\mathrm{i}-\mathrm{C}_{4}$ & $\begin{array}{l}\mathrm{C}_{4} \\
\mathrm{ppb}\end{array}$ & $2-\mathrm{Me}^{-} \mathrm{C}_{4}$ & $\mathrm{i}-\mathrm{C}_{5}$ & $\mathrm{C}_{5}$ & $\begin{array}{l}\text { description on } \\
\text { sampling place }\end{array}$ \\
\hline \multicolumn{11}{|c|}{ Poultry wastes } \\
\hline 1 Aug 11 & 31.4 & $0.1-0.6$ & 1.0 & 0.3 & - & ND & - & $\mathrm{ND}$ & ND & composter room, NIAI \\
\hline 2 Aug 11 & 30.0 & $0.1-0.2$ & 1.0 & 0.9 & - & 0.6 & - & 0.2 & ND & compost storage, NIAI \\
\hline 3 Dec 12 & 18.4 & $0.6-0.7$ & $>30$ & 0.4 & ND & ND & 0.2 & 0.2 & 0.2 & $\mathrm{PL}^{\#}$, Aichi \\
\hline \multicolumn{11}{|c|}{ Cattle wastes } \\
\hline 4 Aug 9 & 34.5 & $0.1 \cdot 1.5$ & - & 1.1 & - & 0.5 & - & 0.1 & ND & compost storage $\#$, NIAI \\
\hline 5 Nov 21 & 22.2 & $0.1-1.0$ & - & 2.9 & $\mathrm{ND}$ & 1.5 & $\mathrm{ND}$ & ND & 1.7 & compost storage \#, NIAI \\
\hline $6 \operatorname{Mar} 20^{*}$ & 18.4 & $0.1-1.8$ & - & 0.2 & 0.1 & ND & ND & ND & ND & compost storage, Mie \\
\hline \multicolumn{11}{|c|}{ Swine wastes } \\
\hline 7 Aug 9 & 34.5 & $0.1-1.4$ & - & 0.1 & - & 0.3 & - & $\mathrm{ND}$ & ND & near aerator, WWTF, NIAI \\
\hline 8 Nov 14 & 15 & moderate & - & 40,8 & 7.7 & 35.5 & 5.1 & 3.3 & 5.1 & PL\#, Saitama \\
\hline $9 \operatorname{Dec} 13$ & 13.2 & $0.1-0.3$ & -- & 0.3 & 0.4 & 0.4 & 0.2 & 0.4 & 1.0 & compost storage $\#$, Aichi \\
\hline $10 \mathrm{Dec} 13$ & 11.8 & $0.3-0.7$ & 3.0 & 0.1 & ND & ND & ND & 0.2 & 0.2 & SD filter**\# for $E$, Aichi \\
\hline $11 \operatorname{Mar} 22^{*}$ & * 19.1 & $0.0-1.4$ & - & 0.1 & 0.2 & 0.1 & ND & ND & ND & near aerator\#, WWTF, Gunma \\
\hline $12 \operatorname{Mar} 22^{*}$ & * 12.8 & $0.9-1.0$ & - & 1.0 & 0.3 & $\mathrm{ND}$ & 0.2 & 0.1 & 0.2 & near lagoon\#, WWTF, Gunma \\
\hline $13 \operatorname{Mar} 22^{*}$ & * 17.6 & $0.0-1.0$ & - & 0.3 & 0.2 & 0.1 & ND & 0.1 & 0.3 & PL\#, ES, WWTF, Gunma \\
\hline
\end{tabular}

mostly removed when the moisture in the exhaust was allowed to condense ${ }^{12,16}$. This indicates that odors from animal wastes can be removed readily if a proper medium for mutual reactions is provided, since the most components of odors have reactive functional groups. In the piggeries with sawdust floors, the sawdust is regarded as such a medium for adsorbing and degrading malodorous substances physicochemically and biologically.

In livestock farms, odors are formed from readily biodegradable organic materials in manure mainly by the action of putrifactory bacteria. Since activities of the bacteria depend on the climatic and atmospheric conditions for the manure, such as temperature, humidity and the redox potential, the seasonal effect in terms of amounts of emitted odorous compounds was expected to occur and evidenced in the determinations of VFA.

However, the effect was not so pronounced on the air of several houses, such as the piggeries with sawdust floors. The reason for preventing the houses from affecting the environment during the hot season may be attributed to the structures and the accomodations in the houses and to the well managed waste treatment, in addition to dilution due to increased ventilation rates in the season.

In this investigation it was shown that emissions of VFA from livestock farms were especially important in swine farms as compared with those from poultry and cattle farms in terms of the regulation by OOCL and that the odors had a close relationship with house structures and facilities, and with the waste management systems; scraping of manure was liable to emitt VFA, whereas in house drying and on-site composting of manure was effective in reducing VFA emittion. The facts that ammonia and VFA were frequently found at the same time in the air of 
VFA in Livestock Facilities

animal houses and of the waste treatment systems, and that in the latter aerial VFA were mostly negligible, indicate a collection of odors from the source by local ventilation and subsequent biological deodorization to be a promising countermeasure for odor complaints. This work was partly supported by a grant from MAFF in 1989.

\section{References}

1) ABE, M., On the revision of the OOCL, J. Odor Res. Eng., 21 : 28-37. 1990.

2) BARTh, C.L., D.T. Hill and L.B. Polkowsk1, Correlating odor intensity index and odorous components in stored dairy manure. Trans. ASAE, $17: 742-744$, 747. 1974.

3) Bell, R.G., Fatty acid content as a measure of the odour potential of stored liquid poultry manure. Poult. Sci., 49 : 1126-1129. 1970

4) Hamano, T., Y. OKa, O. Takada and $T$. Asawo, Study on odorous components in livestock feces. Bull. Hyogo Prefect. Exp. Stn. Anim. Husbandry, (9) : 140-145. 1972.

5) Hoshika, Y., Gas chromatographic determination of traces of $n-$, iso-butyric and $n-$, iso-valeric acids in air using precolumn. Bunseki Kagaku, 27: 382-386. 1978.

6) Hoshika, Y., Gas chromatographic determination of lower fally acids in air at part-per-trillion levels. Anal. Chem., 54 : 2433-2437. 1982.

7) Katou, T., T. Ishiguro and Y. Shigeta,
Akushu no kikisokutei (Instrunental analysis of malodors), 166-179. Kodansha Scientific. Tokyo. 1984.

8) Schaefer, J., Sampling, characrterization and analysis of malodours. Agric. Environ., $3: 121-127.1977$.

9) Spoelstra, S.F., Simple phenols and indoles in anaerobically stored piggery wastes. J. Sci. Food Agric., 28: 415-423. 1977.

10) Spoelstra, S.F., Origin of objectionable odorous components in piggery wastes and the possibility of applying indicator components for studying odor develop. ment. Agric. Environ., 5 : 241-260. 1980.

11) TANAKA, H., Odors of livestock and poultry wastes. Jpn. J. Zootech. Sci., 50 759-767. 1979.

12) Tanaka, H., K. Haga, M. Yonaga and $K$. NAKaJIMA, Control of malodors from swine feces on composting. Proceedings $\mathrm{V}$ WCAP, 2 : 835-836. 1983.

13) Williams, A.G., Indicators of piggery slurry odour offensiveness. Agric. Wastes, $10: 15-36.1984$.

14) Yasuhara, A., Relation between odor and odorous components in solid swine manure. Chemosphere, 9:587-592. 1980.

15) YasuHara, A., Isolation and analysis of odorous components in swine manure. J. Chromatogr., 281 : 225-236. 1983.

16) Yonaga, $M$ and $H$. Tanaka, Studies on odors from livestock wastes and on the control of the odors. Chikusan shikenjo nenpo (Annual report of NIAI), 19: 127145. 1979. 


\section{畜舎および処理施設における低級脂肪酸の発生状況}

田中 博・黒田和孝・長田 隆・代永道裕

鈴木睦美* $・$ 稻葉 満**

農林水産省畜産試験場，茨城県筑波農林研究団地 305

*群馬県農業総合試験場，群馬県富士見村 371-01

**静阔県中小家音試験場, 静岡県菊川町 439

畜産の悪臭の主要成分の一つである低級脂肪酸（VFA）の畜産業からの発生状况を把握し，恶真対 策を確立するために現地調查を史施した。

VFAの分析は環境庁制定のアルカリ・ビーズ法を一部改变して行なった．現地調查は畜試の畜舎， 家畜排泄物処理施設および周辺の養豚場 2 個所を主とし，適宜一般の畜舎施設の調查を加えた。管理が よく、スノコ、ニップル飲水器等を備えた採眀哭鳥舎内のVFA はプロピオン酸 $\left(\mathrm{C}_{3}\right)$ でも $2.4 \mathrm{ppb}$ 以

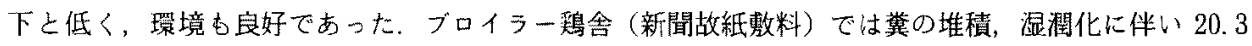

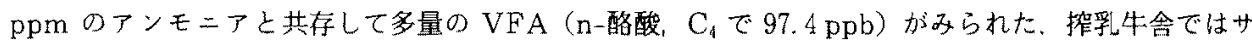

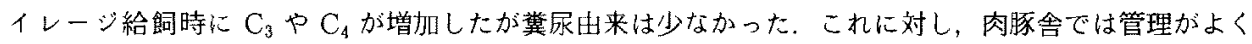
ても VFA はやや高めであった。ささらに周辺の豚舎の子豚舎，肥育舎などでは $\mathrm{C}_{3}, \mathrm{C}_{4}$ は数十 $\mathrm{ppb}$ ，上

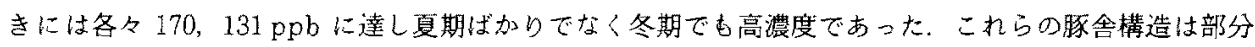
スノコ床構造でスタレーパ、オーガー搬送又は翼尿混合処理であった，一方床の管理のよいオガ屏豚全 では夏冬期とも VFA は $\mathrm{C}_{3}, \mathrm{C}_{4}$ で $5.9,2.2 \mathrm{ppb}$ 以下と比較的低浱度であった，処理施設では豚糞発 酵乾燥施設入口で高い例がみられたが，豚䔬急速堆肥化物置場，堆肥化排気，堆肥盤，鵎戴発醅機室，

同堆積場，同発醉乾蜗施設，污水処理施設等では好理物を含めて VFA は僅かで $\mathrm{C}_{3}, \mathrm{C}_{4}$ で $2.9,1.5$ $\mathrm{ppb}$ 以下であった。

以上, VFA 等の具気の発生には舎内管理だけでなく畜舎構造および施設が特に関連が深いといら結 果がえられた，同時に，生物学的処理過程で容易に除去されることも示唆された。

日畜会報, $62(10) ： 955-962 ， 1991$ 